La Barre, K. (2007). Faceted navigation and browsing features in new OPACs: A more robust solution to problems of information seekers? (extended abstract). Proceedings of the North American Symposium on Knowledge Organization. Vol. 1. Available: http://dlist.sir.arizona.edu/1912

Kathryn La Barre

University of Illinois at Urbana-Champaign, Urbana, Illinois, USA

\title{
Faceted navigation and browsing features in new OPACs: A more robust solution to problems of information seekers?
}

Extended abstract for the position paper submitted to the North American Symposium on Knowledge Organization (NASKO), Toronto, Ontario, 2007. Full paper to appear in Knowledge Organization vol. 34 no. 2 (2007).

Extended abstract: In November, 2005, James Billington, the Librarian of Congress, proposed the creation of a "World Digital Library" of manuscripts and multimedia materials in order to "bring together online, rare and unique cultural materials." Google became the first private sector partner for this project with a pledge of 3 million dollars (http://www.loc.gov/today/pr/2005/05250.html). One month later, the Bibliographic Services Task Force of the University of California Libraries released a report: Rethinking how we provide bibliographic services for the University of California. (Bibliographic Services Task Force, 2005). Key proposals included the necessity of enhancing search and retrieval, redesigning the library catalog or OPAC (Online Public Access Catalog), encouraging the adoption of new cataloguing practices, and supporting continuous improvements to digital access. By mid-January, 2006, the tenor of discussion reached fever pitch. On January 12, 2006, the North Carolina State University (NCSU) Library announced the deployment of a revolutionary implementation for their OPAC of Endeca's ProFind ${ }^{\mathrm{TM}}$, which until now had only been used in commercial e-commerce or other business applications. NCSU made the bold claim that "the speed and flexibility of popular online search engines" had now entered the world of the online catalog through the use of faceted navigation and browsing (NCSU, online).

A few days later, Indiana University posted $A$ White Paper on the Future of Cataloging at Indiana University which served to identify current trends with direct impact on cataloging operations and defined possible new roles for the online catalog and cataloging staff at Indiana University (Byrd et. al, 2006). The Indiana report was a response to an earlier discussion regarding The Future of Cataloging put forth by Deanna Marcum, Director of Public Service and Collection Management at the Library of Congress (Marcum, 2005). Marcum posed a provocative series of questions and assertions based in part on the Pew Internet and American Life Project study: Counting on the Internet (Horrigan and Rainey, 2005). "[D]o we need to provide detailed cataloging information for digitized materials? Or can we think of Google as the catalog?"

Following Marcum's comments, and the announcement of the "World Digital Library", the Library of Congress released a commissioned report in March 2006, The changing nature of the catalog and its integration with other discovery tools" (Calhoun, 2006). This report 
La Barre, K. (2007). Faceted navigation and browsing features in new OPACs: A more robust solution to problems of information seekers? (extended abstract). Proceedings of the North American Symposium on Knowledge Organization. Vol. 1. Available: http://dlist.sir.arizona.edu/1912

contained blueprints for change to Library of Congress cataloguing processes, advocated integration of the catalog with other discovery tools, included suggestions that the Library of Congress Subject Headings LCSH, long used to support subject access to a variety of cultural objects, be dismantled, and argued that fast access to materials should replace the current standard of full bibliographic records for materials. These arguments were supported by assertions that users seem to prefer the ease of Google over the catalog, and that the proposed changes would place the Library of Congress in a better market position to provide users with the services they want most (Fast and Campbell, 2004; OCLC, 2002).

The ensuing debates served to crystallize the intersection and convergence of the traditional missions of the Libraries, Archives and Museum (LAM) communities to provide description, control and access to informational and cultural objects. One consistent theme emerged: What competencies and roles can each community bring to bear upon discussions of digitization, access and discovery, and provide solutions for user needs?

The library community had a ready answer. Originally designed to provide inventory, acquisitions and circulation support for library staff, the modern library catalog was designed according to a set of principles and objectives as described by Charles Ammi Cutter in 1876. These principles and objectives underpin the core competency of the library community to create bibliographic records designed to assist users in the following tasks: to find (by author, title and subject), and to identify, select and obtain material that is of interest to them. Discussions about the aims of the catalog are not new and have been ongoing since the early 1970s when the earliest forays of the catalog into the digital age began (Cochrane, 1978). The role played by metadata (i.e. bibliographic records assembled in catalogs), as well as the central importance of search and retrieval mechanisms have long been central players in proposed solutions to providing better services to users. Thus, the suggestions of staff at the Library of Congress, that digitization is tantamount to access, and that search engines, like Google, may supplant the catalog as the chief means of access to cultural and informational materials, have galvanized action throughout the library and information science community. It is critical that any discussions and recommended solutions maintain a holistic view of the principles and objectives of the catalog.

The actions and continuing discussions that resulted from these developments drew heavily from several sources, including the experiences of the LAM community with the creation of metadata standards, Web 2.0 applications that make data work harder, more accessible and consolidated, the appeal of folksonomy and social classification, and the importance of leveraging rather than abandoning legacy access systems in a time of spiraling costs and decreasing budgets. For archived discussions of these issues see: 1NGC4LIB listserv (Next Generation Catalogs for Libraries http://listserv.nd.edu/archives/ngc4lib.html) and Web4LIB discussion list (http://lists.webjunction.org/web4lib/). Another valuable source is Lorcan Dempsey's blog, Of libraries, services and networks (http://orweblog.oclc.org/).

To leverage some legacy subject access systems it is proposed that more (not less) should be done to process these data, and corresponding authority files (e.g. thesaurus files) in order to use the faceted navigation and browsing features of new online search engines to best advantage. An ongoing research proposal will be described in brief, concentrating on the second goal of a project which plans to develop an integrated conceptual framework which could serve all 
La Barre, K. (2007). Faceted navigation and browsing features in new OPACs: A more robust solution to problems of information seekers? (extended abstract). Proceedings of the North American Symposium on Knowledge Organization. Vol. 1. Available: http://dlist.sir.arizona.edu/1912

designers working on information access and discovery systems. A framework for critical analysis of needed and missing features that is grounded in traditional principles, borne out by practice (Cutter, 1976; La Barre, 2006; Ranganathan, 1962) and which builds on feature analysis protocols for early OPACs is urgently needed (Cochrane, 1978; Hildreth, 1995). Further, another analysis of the sufficiency of current data preparation is long overdue (Anderson and Peréz-Carballo, 2005).

This position paper builds on La Barre (2006, unpublished dissertation) which studied faceted browsing and navigation in websites, using wireframe analysis. This research uncovered features needed for digital library OPAC design. Building on JISC and Sparks work, a future study will focus on the information seeking research academics and the information seekers, rather than the general public, or the overstudied undergraduate user, thus rounding out the work of others cited by Marcum, Kuhlthau, etc.

\section{References:}

Anderson, J. and Peréz-Carballo, P. (2005). Information Retrieval Design: Principles and Options for Information Description, Organization, Display, and Access in Information Retrieval Databases, Digital Libraries, Catalogs, and Indexes. University Publishing Solutions: Omecteca Institute.

Bates, M. (1995). Research Practices of Humanities Scholars in an Online Environment: The Getty Online Searching Project Report No. 3. Library and Information Science Research 17(5), 40.

Bibliographic Services Task Force. (2005). Rethinking how we provide bibliographic services for the University of California. http://libraries.universityofcalifornia.edu/sopag/BSTF/Final.pdf.

Byrd, et.al (2006). A White Paper on the Future of Cataloging at Indiana University http://www.iub.edu/ libtserv/pub/Future_of_Cataloging_White_Paper.pdf.

Calhoun, K. (2006). The changing nature of the catalog and its integration with other discovery tools. FINAL REPORT. Prepared for the Library of Congress. http://www.loc.gov/catdir/calhoun-report-final.pdf.

Carlisle, K. E. (1986). Analyzing Jobs and Tasks. Englewood Cliffs, NJ: Educational Technology Publications, Inc.

Cochrane, P. (1978). Books are for use. Final report of the Subject Access Project to the Council on Library Resources. ERIC Document 156131.

Cutter, C. A. (1876). Rules for a printed dictionary catalogue. Washington : G.P.O.

Fast, K. and Campbell, G. (2004). I Still Prefer Google': University Student Perceptions of Searching OPACS and the Web. Presentation to the ASIST 2004 Annual Meeting, Providence, R.I., Nov. 13-18, 2004. http://www.asis.org/Conferences/AMO4/abstracts/137.html

Flanagan, J. (1954). The Critical Incident Technique. Psychological Bulletin, 51(4), 32759.

Friedlander, A. (2002). Dimensions and Use of the Scholarly Information Environment: 
La Barre, K. (2007). Faceted navigation and browsing features in new OPACs: A more robust solution to problems of information seekers? (extended abstract). Proceedings of the North American Symposium on Knowledge Organization. Vol. 1. Available: http://dlist.sir.arizona.edu/1912

Introduction to a Data Set. DLF/CLIR pub110

http://www.clir.org/pubs/abstract/pub110abst.html

Hildreth, C. (1995). Online Catalog Design Models: Are We Moving in the Right Direction? Washington, D.C.: Commissioned by the Council on Library Resources.

August, 1995. http://myweb.cwpost.liu.edu/childret/clr-opac.html

Horrigan, J. and Rainie, L. (2004). Counting on the Internet. Washington, D.C.: Pew Internet \& American Life Project, 2004. Available at: http://www.pewinternet.org/reports/toc.asp?Report $=80$.

JISC (Joint Information Systems Committee). (2006). http://www.jisc.ac.uk

Kuhlthau, C. (2005). Towards collaboration between information seeking and information retrieval. Information Research 10(2). http://informationr.net/ir/10-2/paper225.html

La Barre, K. (2006). The Use of Faceted Analytico-Synthetic Theory as Revealed in the Practice of Website Construction and Design. Unpublished Dissertation. Indiana University. http://leep.lis.uiuc.edu/publish/klabarre/dissBYsection.html

Marcum, D. (2005). The Future of Cataloging. ALA Midwinter meeting. Ebsco Information Services' Executive Seminar at 2005 Midwinter meeting of the American Library Association, Jan. 16, 2005. Library of Congress. http://www.loc.gov/library/reports/CatalogingSpeech.pdf

Mann, T. (2006a). The changing nature of the catalog and its integration with other discovery tools. Final Report." March 17, 2006. Prepared for the Library of Congress by Karen Calhoun: A Critical Review. http://www.guild2910.org/AFSCMECalhounReviewREV.pdf

Mann, T. (2006b). What is going on at the Library of Congress? http://www.guild2910.org/AFSCMEWhatIsGoingOn.pdf

Marcum, D. (2005). The Future of Cataloging. ALA Midwinter meeting. Ebsco Information Services' Executive Seminar at 2005 Midwinter meeting of the American Library Association, Jan. 16, 2005. Library of Congress. http://www.loc.gov/library/reports/CatalogingSpeech.pdf

Meho, L. and Tibbo, H. (2003). Modeling the information-seeking behavior of social scientists: Ellis's study revisited. JASIST 54(6), 570-587.

Murphy, J. (2003). Information-Seeking Habits of Environmental Scientists: A Study of Interdisciplinary Scientists at the Environmental Protection Agency in Research Triangle Park, North Carolina. Issues in Science \& Technology Librarianship 38.

NCSU. (2006). Endeca at the NCSU Libraries. http://www.lib.ncsu.edu/endeca/

OCLC (2002). White Paper on the Information Habits of College Students. OCLC Online Computer Library Center, Inc. http://www5.oclc.org/downloads/community/informationhabits.pdf

Palmer, C. L. (1996). Information work at the boundaries of science: linking library services to research practices [findings of a study of scientists at an interdisciplinary institute]. Library Trends, 45, 165-91.

Palmer, C. L. and Newmann, K. (2002). The information work of interdisciplinary humanities scholars: exploration and translation. The Library Quarterly 72(1) 85-117. 
La Barre, K. (2007). Faceted navigation and browsing features in new OPACs: A more robust solution to

problems of information seekers? (extended abstract). Proceedings of the North American Symposium on Knowledge Organization. Vol. 1. Available: http://dlist.sir.arizona.edu/1912

Ranganathan, S.R. Elements of Library Classification. Bombay, Calcutta, New Delhi, Madras, London and New York: Asian Publishing House, 1962.

RIN (Research Information Network). http://www.rin.ac.uk/

Rightscom (2006). Researchers and discovery services: Behaviour, perceptions and needs. RIN report. http://www.rin.ac.uk/files/Report\%20-\%20final.pdf

Sparks, S. (2005). Disciplinary Differences and Needs. JISC report. http://www.jisc.ac.uk/uploaded_documents/Disciplinary\%20Differences $\% 20$ and $\% 20 \mathrm{Nee}$ ds.doc

Tenopir, C. (2003). Library Resources: An overview and analysis of recent research studies. CLIR pub. 120 http://www.clir.org/PUBS/reports/pub120/pub120.pdf

Unsworth, J. (2000). John Unsworth,"Scholarly Primitives:What Methods do Humanities Researchers have in common, and how might our Tools reflect this?" Humanities Computing: Formal Methods, Experimental Practice, King's College, London, 13 May 2000. http://www.iath.virginia.edu/ jmu2m/Kings.5-00/primitives.html

Wilson, T.D. Human information behavior. Informing Science, 3(2), 2000. http://inform.nu/Articles/Vol3/v3n2p49-56.pdf 